\title{
Protease-Mediated Suppression of DRG Neuron Excitability by Commensal Bacteria
}

\author{
Jessica L. Sessenwein, ${ }^{1}$ Corey C. Baker, ${ }^{1}$ Sabindra Pradhananga, ${ }^{1}$ Megan E. Maitland, ${ }^{1}$ Elaine 0. Petrof, ${ }^{1}$ \\ Emma Allen-Vercoe, ${ }^{2}$ Curtis Noordhof, ${ }^{1}$ David E. Reed, ${ }^{1}$ Stephen J. Vanner, ${ }^{1}$ and Alan E. Lomax ${ }^{1}$ \\ ${ }^{1}$ Gastrointestinal Disease Research Unit, Queen's University, Kingston, Ontario K7L 2V7, Canada, and 2Department of Molecular and Cellular Biology, \\ University of Guelph, Guelph, Ontario N1G 2W1, Canada
}

Peripheral pain signaling reflects a balance of pronociceptive and antinociceptive influences; the contribution by the gastrointestinal microbiota to this balance has received little attention. Disorders, such as inflammatory bowel disease and irritable bowel syndrome, are associated with exaggerated visceral nociceptive actions that may involve altered microbial signaling, particularly given the evidence for bacterial dysbiosis. Thus, we tested whether a community of commensal gastrointestinal bacteria derived from a healthy human donor (microbial ecosystem therapeutics; MET-1) can affect the excitability of male mouse DRG neurons. MET-1 reduced the excitability of DRG neurons by significantly increasing rheobase, decreasing responses to capsaicin $(2 \mu \mathrm{M})$ and reducing action potential discharge from colonic afferent nerves. The increase in rheobase was accompanied by an increase in the amplitude of voltage-gated $\mathrm{K}^{+}$currents. A mixture of bacterial protease inhibitors abrogated the effect of MET-1 effects on DRG neuron rheobase. A serine protease inhibitor but not inhibitors of cysteine proteases, acid proteases, metalloproteases, or aminopeptidases abolished the effects of MET-1. The serine protease cathepsin G recapitulated the effects of MET-1 on DRG neurons. Inhibition of protease-activated receptor-4 (PAR-4), but not PAR-2, blocked the effects of MET-1. Furthermore, Faecalibacterium prausnitzii recapitulated the effects of MET-1 on excitability of DRG neurons. We conclude that serine proteases derived from commensal bacteria can directly impact the excitability of DRG neurons, through PAR-4 activation. The ability of microbiota-neuronal interactions to modulate afferent signaling suggests that therapies that induce or correct microbial dysbiosis may impact visceral pain.

Key words: electrophysiology; inflammatory bowel disease; intestinal bacteria; nerve-gut interactions; neurogastroenterology

\section{Significance Statement}

Commercially available probiotics have the potential to modify visceral pain. Here we show that secretory products from gastrointestinal microbiota derived from a human donor signal to DRG neurons. Their secretory products contain serine proteases that suppress excitability via activation of protease-activated receptor-4. Moreover, from this community of commensal microbes, Faecalibacterium prausnitzii strain 16-6-I 40 fastidious anaerobe agar had the greatest effect. Our study suggests that therapies that induce or correct microbial dysbiosis may affect the excitability of primary afferent neurons, many of which are nociceptive. Furthermore, identification of the bacterial strains capable of suppressing sensory neuron excitability, and their mechanisms of action, may allow therapeutic relief for patients with gastrointestinal diseases associated with pain.

\section{Introduction}

One of the important functions of the innervation of the gastrointestinal (GI) tract is to convey sensory information about the

Received June 15, 2017; revised 0ct. 23, 2017; accepted 0ct. 26, 2017.

Author contributions: J.L.S., E.O.P., E.A.-V., D.E.R., S.J.V., and A.E.L. designed research; J.L.S., C.C.B., S.P., M.E.M., and C.N. performed research; J.L.S., S.P., E.O.P., E.A.-V., C.N., D.E.R., S.J.V., and A.E.L. analyzed data; J.L.S., E.O.P., E.A.-V., D.E.R., S.J.V., and A.E.L. wrote the paper.

This work was supported by Crohn's and Colitis Canada (operating funding) to A.E.L. and S.J.V., and the National Institutes of Health Grant R21A1121575 to E.A.-V. and E.0.P. We thank Iva Kosatka for technical assistance.

E.O.P and E.A-V. are co-founders of Nubiyota and have filed a patent for MET-1 through Parteq Innovations (Queen's University). The remaining authors declare no competing financial interests.

Correspondence should be addressed to Dr. Alan E. Lomax, GIDRU Wing, Kingston General Hospital, Kingston, Ontario K7L2V7, Canada. E-mail: Iomaxa@queensu.ca. luminal milieu to the brain. A major component of the gut lumen is a complex and dynamic microbial ecosystem that contributes importantly to health and disease, and may impact animal behavior (Lyte, 2014; Cryan and Dinan, 2015). It has recently been proposed that gut bacteria and/or their metabolites can affect both the motor and sensory innervation of the gut, leading to altered function and visceral pain (Chichlowski and Rudolph, 2015). However, despite ongoing research, the cellular mecha-

DOI:10.1523/JNEUROSCI.1672-17.2017

Copyright $\odot 2017$ the authors $\quad 0270-6474 / 17 / 3711758-11 \$ 15.00 / 0$ 
nisms leading to bacterial modulation of visceral pain remain incompletely understood.

A potential mechanism was suggested by a recent study of the pain associated with pathogenic bacterial infection of the skin by Staphylococcus aureus. Chiu et al. (2013) demonstrated that the pain associated with this infection was due to direct effect of $S$. aureus bacteria on DRG neuron excitability, rather than an indirect consequence of the immune response to infection. This suggests that some pathogenic bacteria and their secretory products directly influence DRG neuron excitability, not just via conventional pattern recognition molecules, such as Toll-like receptors (Ochoa-Cortes et al., 2010), but also via novel mediators released from bacteria. Inflammatory bowel disease (IBD), irritable bowel syndrome (IBS), and psychological stress are all conditions associated with visceral pain (Soderholm et al., 2001; Sánchez de Medina et al., 2014), and a contribution of the microbiota to pain generation in these conditions has been suggested (Kamiya et al., 2006; Rousseaux et al., 2007; McKernan et al., 2010; Duncker et al., 2011; Perez-Burgos et al., 2015). These latter studies have been pivotal in highlighting the potential for bacteria to signal to nociceptive neurons; however, many of these studies have relied on one or a few commercially available probiotic bacteria. Thus, our primary goal was to enhance understanding of how the healthy human intestinal microbiota contributes to visceral pain by examining the bacterial mediators and cellular mechanisms involved in communication between this community and sensory neurons. We hypothesized that secretory products from commensal gut bacteria can directly signal to DRG neurons and affect their excitability. Accordingly, we determined whether the secretory products of a defined community of 33 commensal GI microbes from a healthy human donor, microbial ecosystem therapeutics-1 (MET-1) (Petrof et al., 2013; Martz et al., 2015; Munoz et al., 2016), alter neuronal excitability and whether a specific secretory mediator is responsible for any alterations observed. We found that these bacteria reduced the excitability of DRG neurons, determined the mechanisms involved, and examined whether MET-1 could reverse the hyperexcitability of DRG neurons caused by colitis.

\section{Materials and Methods}

Animals. All experiments were approved by Queen's University Animal Care Committee, under the guidelines of the Canadian Council of Animal Care. Male C57BL/6 mice (25-30 g) were obtained from Charles River Laboratories.

DRG neuron culture. Mice were killed, and DRGs from thoracic vertebra T9 to T13 were isolated bilaterally and dissociated as described previously (Beyak et al., 2004). Briefly, dissected DRGs were incubated for $10 \mathrm{~min}$ at $37^{\circ} \mathrm{C}$ in $\mathrm{HBSS}$ containing $0.2 \mathrm{mg} / \mathrm{ml}$ papain activated with 0.4 $\mathrm{mg} / \mathrm{ml}$ cysteine. This was followed by a $10 \mathrm{~min}$ incubation in HBSS containing $290 \mathrm{U} / \mathrm{ml}$ collagenase Type II and $10 \mathrm{U} / \mathrm{ml}$ dispase II. Ganglia were triturated 10 times through flame-polished Pasteur pipettes until a single-cell suspension was obtained. Cells were plated onto coverslips coated with laminin $(50 \mu \mathrm{g} / \mathrm{ml})$ and poly-D-lysine $(100 \mu \mathrm{g} / \mathrm{ml})$ and incubated overnight at $37^{\circ} \mathrm{C}$ ( $95 \%$ air, $5 \% \mathrm{CO}_{2}$ ) in F-12 medium supplemented with $10 \%$ heat-inactivated FBS and $1 \%$ penicillin/streptomycin. Neurons were incubated in control media or media containing a dilution of MET-1 supernatant during the first night in culture.

Retrograde labeling on colon-projecting DRG neurons. Mice were deeply anesthetized with ketamine/xylazine $(0.1 \mathrm{ml} / 10 \mathrm{mg}$ body weight $)$. After the animals stopped responding to a firm pinch of the hind foot, a laparotomy was performed and the colon located and exposed; $2-4$ injections of fast blue ( $17 \mathrm{mg} / \mathrm{ml}$ in DMSO) were made ( $\sim 5 \mu$ per injection) via a Hamilton syringe in the wall of the proximal colon. Once injections were completed, the area was swabbed with cotton swabs to ensure no leakage of the dyes to other areas of the colon. The muscle and skin was then sutured, and the animals were left to recover in a warm environment under constant supervision. Once the animals returned to normal behaviors, they were returned to standard animal housing and left at least $14 \mathrm{~d}$ before removing the DRG.

Patch-clamp electrophysiology. Following overnight culture, glass coverslips containing isolated cells were placed in a recording chamber on an inverted microscope and superfused with solution containing the following (in mM): $140 \mathrm{NaCl}, 5 \mathrm{KCl}, 1 \mathrm{MgCl}_{2}, 2 \mathrm{CaCl}_{2}, 10 \mathrm{HEPES}$, and 10 D-glucose, $\mathrm{pH}$ 7.4, with $\mathrm{NaOH}$. Patch electrodes were pulled from Premium Custom 8520 Patch Glass (Warner Instruments) and polished to a final resistance of $2-5 \mathrm{~m} \Omega$ when filled with an internal pipette solution containing the following (in $\mathrm{mm}$ ): $110 \mathrm{~K}$-gluconate, $30 \mathrm{KCl}, 10 \mathrm{HEPES}$, $1 \mathrm{MgCl}_{2}$, and $2 \mathrm{CaCl}_{2}$, pH 7.25, with KOH. Amphotericin B $(240 \mu \mathrm{g} / \mathrm{ml})$ was added to the pipette solution, and recordings were performed using the perforated patch-clamp configuration. For recordings of sodium currents, cells were superfused with solution containing the following (in mM): $55 \mathrm{NaCl}, 80 \mathrm{NMDG}, 1 \mathrm{MgCl}_{2}, 1 \mathrm{CaCl}_{2}, 10$ HEPES, and $5 \mathrm{D}$-glucose, $\mathrm{pH} 7.4$, with $\mathrm{HCl}$. Polished pipettes were filled with internal pipette solution contained the following (in mM): $110 \mathrm{CsCl}, 1 \mathrm{Mg} \mathrm{Cl}_{2}, 11$ EGTA, 10 HEPES, and $10 \mathrm{NaCl}, \mathrm{pH} 7.3$, with $\mathrm{CsOH}$. Recordings were performed using the whole-cell configuration.

We limited our electrophysiological recordings to small-diameter DRG neurons ( $\leq 30 \mathrm{pF}$ ) (Stewart et al., 2003) to maximize the number of putative nociceptor neurons sampled. Cells with stable $(<10 \%$ variation over $120 \mathrm{~s}$ ) resting membrane potentials more negative than $-40 \mathrm{mV}$ and overshooting action potentials were used for data collection. Changes in neuronal excitability were assessed by determining rheobase, the first action potential elicited by a series of depolarizing current injections ( 500 $\mathrm{ms}$ ) that increased in $10 \mathrm{pA}$ increments (Valdez-Morales et al., 2013b). Action potential frequency was determined by quantifying the number of action potentials elicited in response to depolarizing current injections (500 ms). Input resistance was determined by the hyperpolarizing response to current step from -10 to $0 \mathrm{pA}$. Membrane capacitance and series resistance were compensated by $70 \%-80 \%$, and liquid junction potentials were corrected. Current-voltage $(I-V)$ relationships were measured using a series of $500 \mathrm{~ms}$ step depolarizations $(-100 \mathrm{mV}$ to $50 \mathrm{mV}$ in $10 \mathrm{mV}$ increments at $5 \mathrm{~s}$ intervals) from holding potential. Current density was calculated by normalizing peak currents to cell capacitance.

Signals were amplified using an Axopatch 200B or Multiclamp 700B amplifier and digitized with a Digidata 1322A A/D converter. Liquid junction potentials were calculated using JPCalcW (Molecular Devices) and corrected offline. Data were recorded onto a PC using pClamp software and analyzed offline using Clampfit 10.0 (all from MDS Analytical Technologies).

In vitro extracellular recordings. The colon $(5-6 \mathrm{~cm})$ and attached mesentery (containing the lumbar colonic nerves) were removed intact, along with the attached neurovascular bundle as described previously (Brierley et al., 2004). In brief, the distal colon was carefully opened along the mesenteric border, with care taken not to damage mesenteric nerves, and placed in a specialized organ bath. Preparations were superfused with a modified Krebs' solution containing the following (in $\mathrm{mm}$ ): 117.9 $\mathrm{NaCl}, 4.7 \mathrm{KCl}, 25 \mathrm{NaHCO}_{3}, 1.3 \mathrm{NaH}_{2} \mathrm{PO}_{4}, 1.2 \mathrm{MgSO}_{4}\left(\mathrm{H}_{2} \mathrm{O}\right)_{7}, 2.5 \mathrm{CaCl}_{2}$ $11.1 \mathrm{D}$-glucose, 2 sodium butyrate, and 20 sodium acetate), bubbled with carbogen $\left(95 \% \mathrm{O}_{2} / 5 \% \mathrm{CO}_{2}\right)$ at a temperature of $34^{\circ} \mathrm{C}$. All preparations contained the L-type calcium channel antagonist nifedipine $(1 \mu \mathrm{M})$ to suppress smooth muscle activity and the prostaglandin synthesis inhibitor indomethacin $(3 \mu \mathrm{M})$ to suppress potential inhibitory actions of endogenous prostaglandins (Lynn and Blackshaw, 1999). Using fine forceps, the nerve trunk was teased apart into $6-10$ bundles, one of which was placed onto a platinum recording electrode. A platinum reference electrode rested on the mirror in a small pool of Krebs' solution adjacent to the recording electrode. Electrical signals generated by nerve bundles were amplified, filtered, and sampled at a rate of $20 \mathrm{kHz}$ using a 1401 interface (Cambridge Electronic Design). Action potentials were analyzed off-line using the Spike 2 wave mark function and discriminated as single units on the basis of distinguishable waveform, amplitude, and duration. Baseline action potential discharge was measured for $3 \mathrm{~min}$ before superfusion of MET-1 supernatant (1:100) for $10 \mathrm{~min}$. Action potential discharge frequency was measured again over the final $3 \mathrm{~min}$ of exposure to MET-1 and compared with baseline. 
Table 1. List of cultured isolates from the healthy donor comprising the MET-1 synthetic microbial community ${ }^{a}$

\begin{tabular}{|c|c|c|}
\hline $\begin{array}{l}\text { Strain number } \\
\text { (16-6-I prefix) }\end{array}$ & Species name (closest match) & $\begin{array}{l}\text { Relative amount } \\
\text { included in MET-1 }\end{array}$ \\
\hline $\begin{array}{l}1 F A A \\
29 F A A\end{array}$ & Eubacterium rectale & +++++ \\
\hline 40FAA & Faecalibacterium prausnitzii & +++++ \\
\hline F1FAA & Eubacterium eligens & +++++ \\
\hline $\begin{array}{l}\text { 30FAA } \\
\text { 9FAA }\end{array}$ & Ruminococcus torques & +++ \\
\hline $\begin{array}{l}4 \mathrm{FM} \\
2 \mathrm{FAA}\end{array}$ & Bifidobacterium longum & +++ \\
\hline $\begin{array}{l}14 \mathrm{LG} \\
31 \mathrm{FAA} \\
39 \mathrm{FAA} \\
6 \mathrm{FM}\end{array}$ & $\begin{array}{l}\text { Acidaminococcus intestini } \\
\text { Roseburia sp. }\end{array}$ & $\begin{array}{l}+++ \\
++\end{array}$ \\
\hline $\begin{array}{l}11 F A A \\
20 M R S\end{array}$ & Bifidobacterium adolescentis & ++ \\
\hline $5 F M$ & Parabacteroides distasonis & ++ \\
\hline 47FAA & Eubacterium ventriosum & ++ \\
\hline $2 M R S$ & Ruminococcus obeum & + \\
\hline 18FAA & Clostridium clostridioforme & + \\
\hline $3 F M$ & Collinsella aerofasciens & + \\
\hline $5 \mathrm{MM}$ & Bacteroides ovatus & + \\
\hline $\begin{array}{l}27 \mathrm{FM} \\
11 \mathrm{FM}\end{array}$ & Blautia sp. & + \\
\hline $\begin{array}{l}\text { 42FAA } \\
10 F A A\end{array}$ & Doreasp. & + \\
\hline 21FAA & Coprobacillus sp. & + \\
\hline $13 \mathrm{LG}$ & Eubacterium limosum & + \\
\hline 25MRS & Lactobacillus casei & + \\
\hline $6 \mathrm{MRS}$ & Lactobacillus paracasei & + \\
\hline 34FAA & Lachnospira pectinoshiza & + \\
\hline 48FAA & Butrycicoccus sp. & + \\
\hline 3FM4i & Escherichia coli & + \\
\hline 6BF7 & Raoultella sp. & + \\
\hline $1 S t$ & Streptococcus sp. & + \\
\hline
\end{tabular}

${ }^{a}$ The strain number of each isolate (left) and the relative abundance in the community (right) is also provided. Modified from Petrof et al. (2013).

Ratiometric $\mathrm{Ca}^{2+}$ imaging. Neurons were incubated in $4 \mu \mathrm{M}$ fura-2 $\mathrm{AM}$ (dissolved in DMSO, Invitrogen) for $30 \mathrm{~min}$ at $37^{\circ} \mathrm{C}$. Neurons were washed with extracellular solution to remove excess extracellular fura-2 AM. Composition of extracellular solution is as follows (in mM): $140 \mathrm{NaCl}, 5$ $\mathrm{KCl}, 1 \mathrm{MgCl}_{2}, 2 \mathrm{CaCl}_{2}, 10 \mathrm{HEPES}$, and $10 \mathrm{D}$-glucose, $\mathrm{pH}$ 7.4. Extracellular solution was adjusted to $\mathrm{pH} 7.4$ using $\mathrm{NaOH}$. Circular glass coverslips were mounted in a recording chamber on an inverted microscope (IX73, Olympus) and superfused continuously with external solution at room temperature. Changes in fluorescence intensity were measured using MetaFlour Fluorescence Imaging Software (Molecular Devices). Neurons were illuminated at 340 and $380 \mathrm{~nm}$ every second for $10 \mathrm{~min}$ with a Lambda DG-4 Plus high-speed wavelength switcher (Sutter Instruments) and a Rolera Thunder camera (QImaging). Regions of interest were selected beneath the membrane of neurons. Using the region of interest, the averaged pixel intensity was calculated. Paired 340/380 fluorescence ratios ( $\mathrm{f} 340: 380$ ) of each region of interest were calculated every second. $\left[\mathrm{Ca}^{2+}\right]_{i}$ was determined as the ratio of the fluorescence signals obtained at $510 \mathrm{~nm}$ following excitation at 340 and $380 \mathrm{~nm}$. TRPV1 channels were activated by superfusion of capsaicin $(2 \mu \mathrm{M})$ for 3 min. The peak increase in $\mathrm{f} 340: 380$ in the presence of capsaicin was expressed as a percentage of the baseline f340:380 ratio. Cells were defined as having responded to capsaicin if their baseline f $340: 380$ changed by $>20 \%$ following exposure to capsaicin.

Derivation of MET-1. The derivation of MET-1, commensal colonic bacteria from a healthy human volunteer, was described in detail previously (Petrof et al., 2013). In brief, the 33 MET-1 isolates (Table 1) were cultured individually on fastidious anaerobe agar (FAA) (Lab M) with or without 5\% defibrinated sheep blood (Hemostat Laboratories) under anaerobic conditions. FAA plates and F12 media were degassed in anaerobic chamber for $24 \mathrm{~h}$ before use. Bacteria were incubated at $37^{\circ} \mathrm{C}$ for $3 \mathrm{~d}$ under strict anaerobic conditions in a Bugbox (Ruskinn). Biomass, in the appropriate proportions (Table 1), was scraped directly into filtersterilized F12 medium using microbiological loops to achieve $3.5 \times 10^{9}$ $\mathrm{CFU} / \mathrm{ml}$ (Petrof et al., 2013). Biomass was carefully mixed in the F12 media using a sterile pipette tip. MET-1 isolates in F12 medium were kept in an anaerobic chamber for $6 \mathrm{~h}$ at $37^{\circ} \mathrm{C}$ and then stored at $-80^{\circ} \mathrm{C}$. Before use, supernatant was removed, centrifuged, and filter sterilized. Individual bacterial strains were derived in the same manner. MET-1 minus Faecalibacterium prausnitzii strain 16-6-I 40 FAA was derived in the same fashion, except with the omission of this single bacterial strain.

Reagents. Amphotericin B (Sigma-Aldrich) stock solution $\left(60 \mu \mathrm{g} \mu \mathrm{l}^{-1}\right.$ DMSO) was made fresh daily. HBSS, FBS, and F12 medium for tissue culture were purchased from Invitrogen. Dextran sulfate sodium (DSS) was purchased from MP Biomedicals. P4pal10 (pal-SGRRYGHALR) peptide was synthesized by Biomatix. All other substances were purchased from Sigma-Aldrich.

Statistical analysis. Data are mean \pm SEM. The $n$ value on each bar refers to the number of neurons in the corresponding group. The number of mice used for each experiment is reported as $N$. Statistical analysis was performed in Prism 5 for Mac OS X using Student's $t$ tests, one-way ANOVA followed by Newman-Keuls test, Kruskal-Wallis test followed by Dunn's post hoc test (for nonparametric data), or two-way ANOVA with Bonferroni post hoc test where appropriate. Statistical significance was assigned when $p<0.05$.

\section{Results}

\section{Effects of MET-1 on neuronal excitability}

To determine whether secreted products of the bacteria in MET-1 could alter the excitability of primary sensory neurons, we incubated DRG neurons overnight in MET-1 supernatant. MET-1 supernatant decreased the excitability of DRG neurons, by increasing the rheobase in a concentration-dependent manner (Fig. $1 A ; F_{(4,88)}=6.003, p=0.0003$, one-way ANOVA with Kruskal-Wallis test followed by Dunn's post hoc test). A dilution of 1:100 MET-1 increased rheobase by $32 \%$ compared with controls and was used for all subsequent experiments. MET-1 did not alter action potential discharge at twice rheobase (data not shown). The following additional parameters were not altered at a dilution of 1:100 MET-1 $(n=25)$ compared with media $(n=$ $34)$ : input resistance $(1313 \pm 117.8 \mathrm{M} \Omega$ vs $1172 \pm 77.9 \mathrm{M} \Omega)$, capacitance $(17.3 \pm 0.7 \mathrm{pF}$ vs $17.6 \pm 0.8 \mathrm{pF})$, resting membrane potential $(-46.3 \pm 3.1 \mathrm{mV} v s-43.5 \pm 1.8 \mathrm{mV})$, action potential duration at half-maximal amplitude $(3.35 \pm 0.17 \mathrm{~ms}$ vs $3.47 \pm$ $0.14 \mathrm{~ms})$, action potential threshold $(-31.5 \pm 1.6 \mathrm{mV}$ vs $-30.0 \pm$ $1.8 \mathrm{mV})$, or after-hyperpolarization amplitude $(9.9 \pm 1.3 \mathrm{mV}$ vs $11.3 \pm 1.1 \mathrm{mV})$, respectively. To determine whether MET-1 had effects on DRG neurons that project to the colon, fast blue was injected into the colon of mice as a retrograde tracer. Two weeks later, the rheobase of fast blue-labeled neurons was recorded. Similar to unlabeled neurons, colon-projecting DRG neurons exposed to MET-1 supernatant (1:100) overnight had significantly higher rheobases compared with colon-projecting neurons exposed to control media (Fig. $1 B ; t_{(14)}=2.89, p=0.0119$, unpaired Student's $t$ test).

Extracellular recordings from the axons of extrinsic afferent neurons revealed that application of MET-1 supernatant $(1: 100)$ for $10 \mathrm{~min}$ significantly reduced spontaneous action potential discharge compared with baseline activity measured before MET-1 application in the same single units (Fig. $1 C ; t_{(8)}=2.95, p=0.0185$, paired Student's $t$ test). Ratiometric $\mathrm{Ca}^{2+}$ imaging using fura-2 was used to quantify the effect of MET-1 on intracellular $\mathrm{Ca}^{2+}$ responses of DRG neurons to capsaicin. MET-1 had no effect on the percentage of DRG neurons that responded to capsaicin 
A

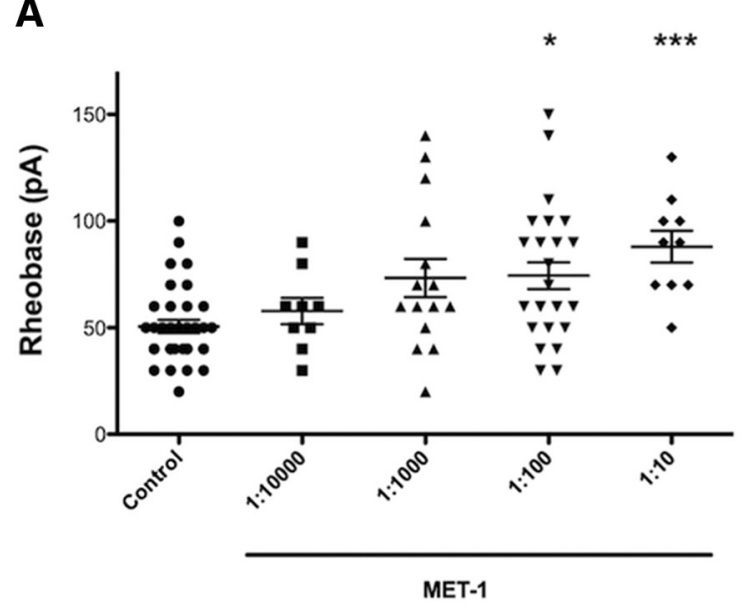

C

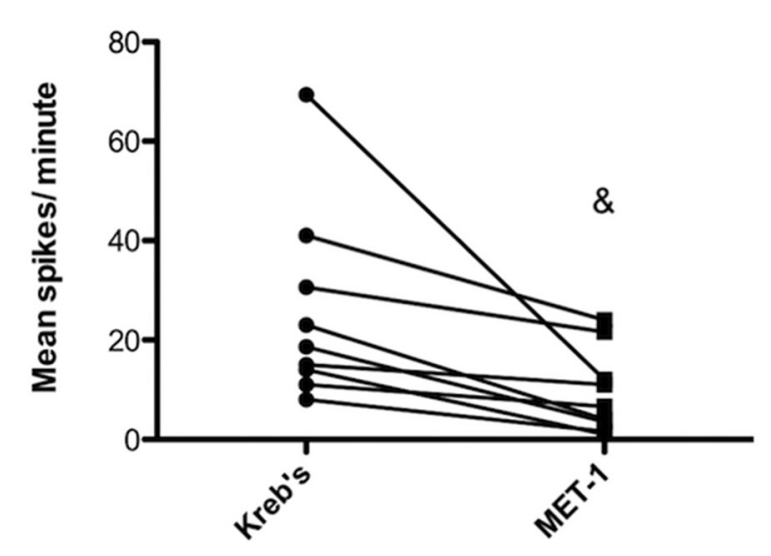

B

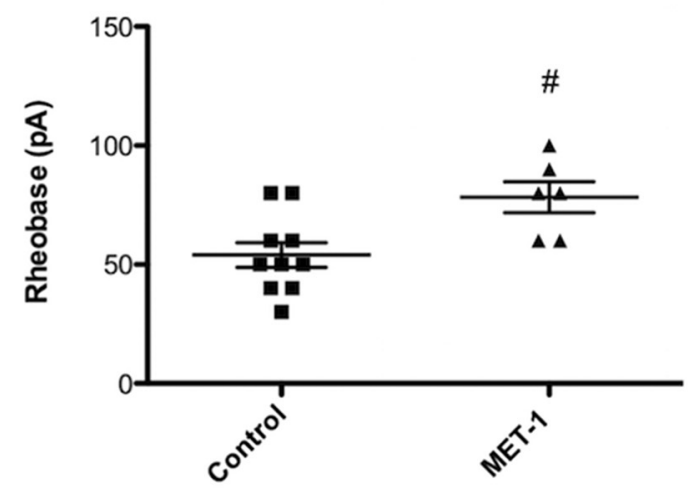

D

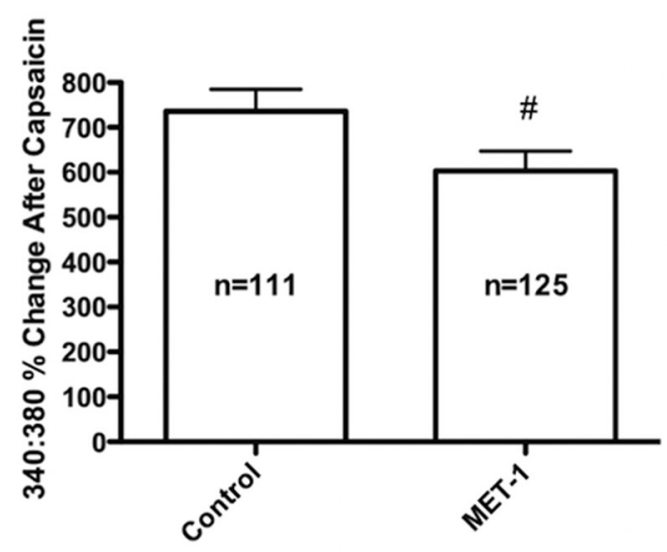

Figure 1. MET-1 decreases excitability of DRG neurons. $A$, MET-1 (1:100 and 1:10) decreased the excitability of DRG neurons by increasing rheobase compared with media $(N=10$ mice). $B$, MET-1 (1:100) increased the excitability of DRG neurons that innervate the colon, identified using the retrograde tracer fast blue $(N=3$ mice). $C$, Superfusion of MET-1 (1:100) decreased spontaneous action potential discharge in single-unit extracellular recordings from the axons of colonic afferent neurons $\left(N=4\right.$ mice). $\boldsymbol{D}$, The amplitude of intracellular [ $\left[\mathrm{a}^{2+}\right.$ ] transients in response to capsaicin $(2 \mu \mathrm{M})$, measured using fura-2 f340:380, was decreased in DRG neurons incubated in MET-1 (1:100) $\left(N=5\right.$ mice). ${ }^{*} p<0.05$ (one-way ANOVA with Kruskal-Wallis test followed by Dunn's post hoc test). ${ }^{* * *} p<0.001$ (one-way ANOVA with Kruskal-Wallis test followed by Dunn's post hoc test). ${ }^{*} p<0.05$ (unpaired $t$ test). ${ }^{\&} p<0.05$ (paired $t$ test).

(control: 59\% vs MET-1: 58\%; $p>0.05$, Fisher's exact test) but significantly decreased the amplitude on the $\mathrm{Ca}^{2+}$ transient, as measured by change in $\mathrm{f340:380} \mathrm{(Fig.} 1 D ; t_{(234)}=2.01, p=$ 0.0460 , unpaired Student's $t$ test). Together, these data suggest that secretory products of MET-1 can inhibit the excitability of DRG neurons, including those that innervate the colon.

Voltage-clamp recordings were obtained to examine the role of voltage-gated $\mathrm{K}^{+}$and $\mathrm{Na}^{+}$currents in the decrease in DRG excitability observed in response to MET-1. MET-1 significantly increased voltage-gated $\mathrm{K}^{+}$current (Fig. $2 A, B ; F_{(15,345)}=8.852$, $p<0.0001$, two-way ANOVA followed by Newman-Keuls test post hoc test) compared with controls but did not affect voltagegated $\mathrm{Na}^{+}$current (Fig. 2C).

\section{Heat-labile effects of MET- 1 on neuronal excitability}

To examine the properties of the active mediator in MET- 1 supernatant, we tested whether the MET-1 secreted mediator(s) causing this effect is/are heat-labile. Thus, MET-1 supernatant was heated to $100^{\circ} \mathrm{C}$ for $20 \mathrm{~min}$, followed by cooling (Mackey et al., 1991) before addition to DRG neuron cultures overnight. The effects of MET-1 on excitability of DRG neurons were abolished following heat treatment (Fig. 3; $F_{(2,58)}=11.26, p<0.0001$, one-way ANOVA followed by Newman-Keuls test post hoc test).
Protease-mediated effects of MET- 1 on neuronal excitability

Because heat-sensitive proteases can be produced by enteric bacteria and are well-characterized modulators of excitability in DRG neurons (Kayssi et al., 2007; Karanjia et al., 2009; Steck et al., 2012; Valdez-Morales et al., 2013a), we sought to determine whether the active mediator in MET-1 supernatant could be a protease. To examine this, MET- 1 was preincubated with a bacterial protease inhibitor (PI) mixture for $2 \mathrm{~h}$ (Sigma, P8465; 1:10,000) (Borruel et al., 2002) before incubation with DRG neurons. The decreased excitability of DRG neurons by MET- 1 was prevented by addition of the PI mixture, suggesting that the active mediator is a protease (Fig. $4 A ; F_{(3,41)}=4.996, p=0.0048$, oneway ANOVA followed by Newman-Keuls test post hoc test). Because the PI mixture contained inhibitors of cysteine, acid proteases, metalloproteases, aminopeptidases, and serine proteases (Borruel et al., 2002), we next explored the effects of selective inhibitors of each of these subtypes of proteases. The decreased excitability of DRG neurons by MET-1 was prevented following preincubation for $2 \mathrm{~h}$ with the serine PI FUT-175 (100 $\mu \mathrm{M}$ ) (Cenac et al., 2007) (Fig. $4 B ; F_{(3,59)}=4.211, p=0.0091$, one-way ANOVA followed by Newman-Keuls test post hoc test) but not other individual PIs (cysteine, acid proteases, metalloproteases, aminopeptidases) (Fig. 4C). Additionally, we investi- 
A

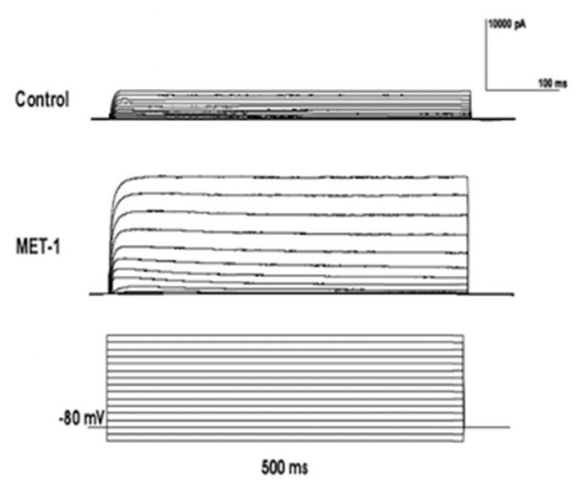

C

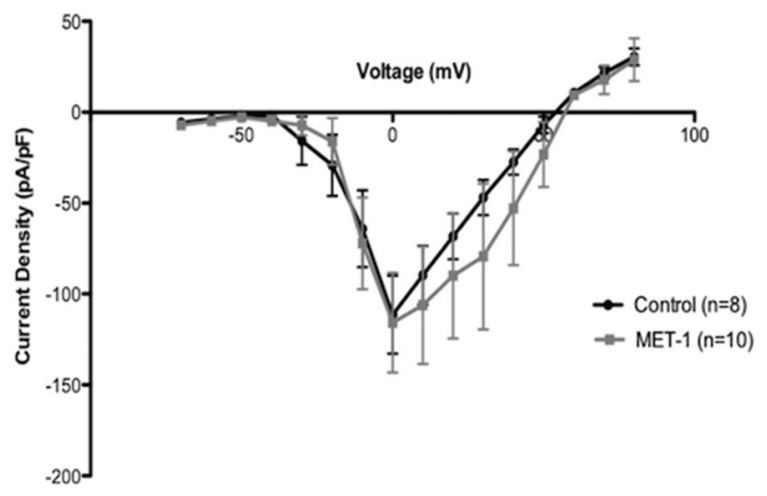

B

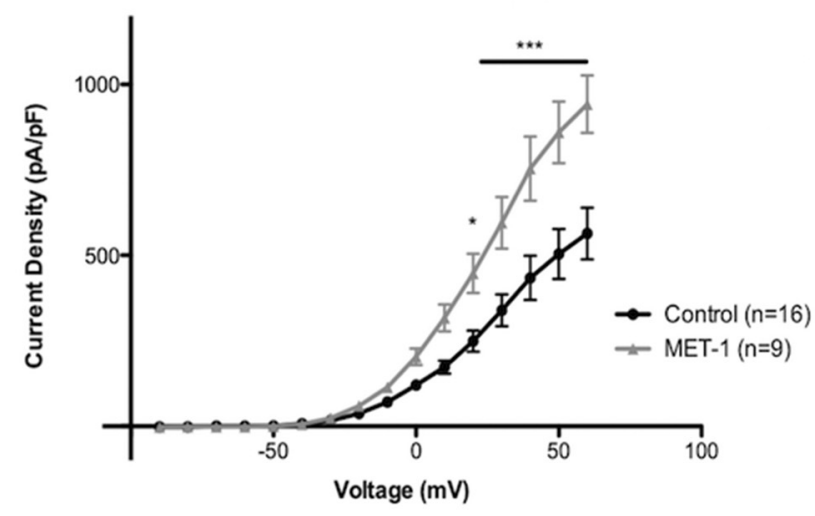

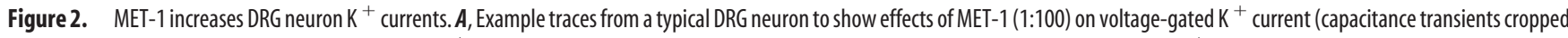
for space). B, MET-1 (1:100) increased voltage-gated $\mathrm{K}^{+}$current compared with media ( $N=8$ mice). C, MET-1 did not alter the voltage-gated Na ${ }^{+}$currents $\left(N=6\right.$ mice). ${ }^{*} p<0.05$ (two-way ANOVA with Bonferroni post hoc test). ${ }^{* * *} p<0.001$ (two-way ANOVA with Bonferroni post hoc test).

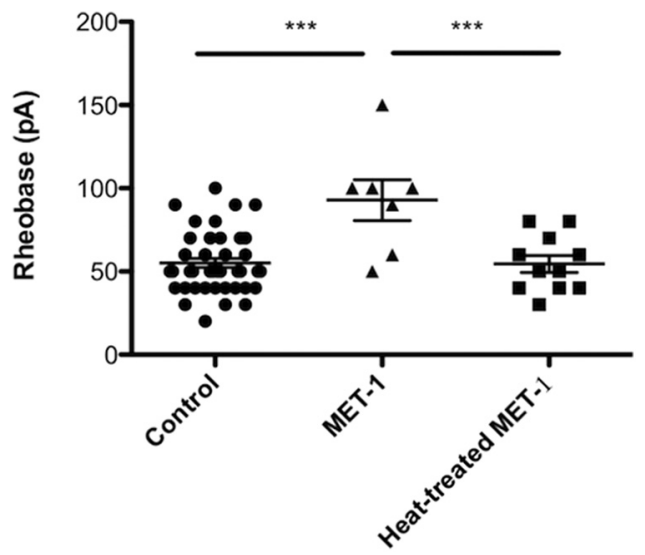

Figure 3. Effects of MET-1 on DRG neuron excitability are abolished following heat treatment. MET-1 decreased the excitability of DRG neurons by increasing rheobase compared with media; this effect was abolished following heat treatment $\left(100^{\circ} \mathrm{C}\right.$ for $\left.20 \mathrm{~min}\right)$ of MET- $1(\mathrm{~N}=3$ mice). ${ }^{* *} p<0.001$ (one-way ANOVA with Newman-Keuls post hoc test).

gated whether a known serine protease, cathepsin G (Cat G), could recapitulate the effects of MET-1 on DRG neurons. Cat G was chosen as it has been identified as an activator of PAR-4 (Asfaha et al., 2007). Cat G concentration-dependently decreased excitability of DRG neurons by increasing rheobase by $43 \%$ compared with controls (Fig. $4 D ; F_{(4,52)}=4.796, p=0.0023$, one-way ANOVA followed by Newman-Keuls test post hoc test).

\section{PAR-4-mediated effects of MET-1 on neuronal excitability}

Because serine proteases are known to act on PARs, which are present on DRG neurons, we sought to determine whether MET-1 acts via a PAR (Bunnett, 2006; Dale and Vergnolle, 2008). PAR-4 is activated by serine proteases, and its activation has previously been shown to decrease DRG neuron excitability (Asfaha et al., 2007; Karanjia et al., 2009). Preincubation of DRG neurons with P4pal10 $(10 \mu \mathrm{M})$, a PAR-4 pepducin (Wielders et al., 2007) that inhibits PAR-4 activation, for $2 \mathrm{~h}$ before the addition of MET-1 abolished the effect of MET- 1 on neuron excitability (Fig. $5 A ; F_{(3,98)}=4.347, p=0.0064$, one-way ANOVA followed by Newman-Keuls test post hoc test). We also investigated whether MET-1 secreted serine proteases that act in part through PAR-2 expressed on DRG neurons (Valdez-Morales et al., 2013a). Preincubation of DRG neurons with GB83 $(10 \mu \mathrm{M})$ (Valdez-Morales et al., 2013a), a PAR-2 antagonist, for $2 \mathrm{~h}$ before the addition of MET-1 did not inhibit the effect of MET-1 on neuron excitability (Fig. $5 B ; F_{(3,84)}=4.274, p=0.0074$, one-way ANOVA followed by Newman-Keuls test post hoc test).

\section{NF $\kappa$ B- and ERK1/2-mediated effects of MET-1 on neuronal excitability}

We next examined the intracellular signaling cascades evoked by MET-1 supernatant. Preincubation of DRG neurons with SC-514 $(20 \mu \mathrm{M})$, an NF $\kappa \mathrm{B}$ inhibitor (Kishore et al., 2003), for $2 \mathrm{~h}$ before the addition of MET-1 prevented the decrease in excitability of DRG neurons by MET-1 (Fig. $6 A ; F_{(3,61)}=7.878, p=0.0002$, one-way ANOVA followed by Newman-Keuls test post hoc test). 
A

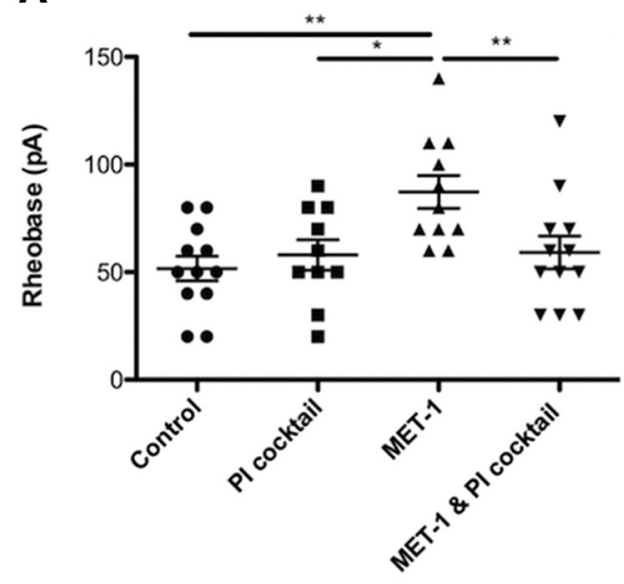

B

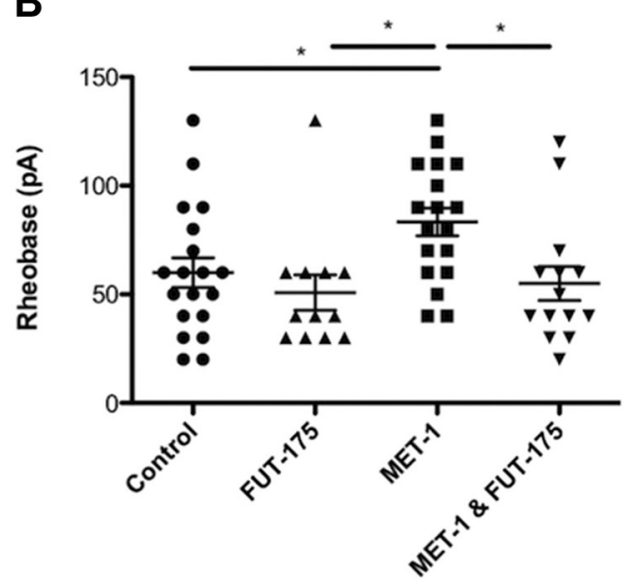

D

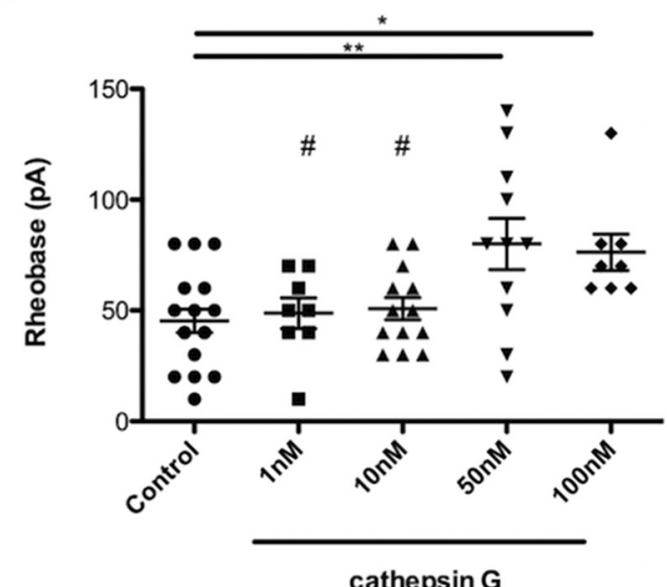

Figure 4. Effects of MET-1 on DRG neuron excitability is mediated in part by serine proteases. $A, M E T-1$ decreased excitability of DRG neurons by increasing rheobase compared with media; this effect was abolished following addition of the PI mixture $(1: 10,000)(N=9$ mice). $B$, MET-1 decreased excitability of DRG neurons by increasing rheobase compared with media; this effect was abolished following addition of the serine PI FUT-175 $(100 \mu \mathrm{M})(N=10$ mice). $C$, The effect of MET-1 on the decrease in excitability of DRG neurons was not abolished following addition of a cysteine $\mathrm{PI}(\mathrm{E} 64 ; 0.03 \mu \mathrm{M})$, aminopeptidase inhibitor (bestatin; $0.20 \mu \mathrm{M})$, acid PI (pepstatin; $0.03 \mu \mathrm{M})$, or metallo-PI (EDTA; $10 \mu \mathrm{M})(N=3-5$ mice/group). D, The serine protease, cathepsin G $(1,10,50$, and $100 \mathrm{~nm}$ ) concentration-dependently recapitulated the effects of MET- 1 on excitability of DRG neurons by increasing rheobase compared with media ( $N=5$ mice). ${ }^{*} p<0.05$ (one-way ANOVA with Newman-Keuls post hoc test). ${ }^{* *} p<0.01$ (one-way ANOVA with Newman-Keuls post hoc test). ${ }^{\#} p<0.05$ compared with $50 \mathrm{~nm}$ (one-way ANOVA with Newman-Keuls post hoc test).

A

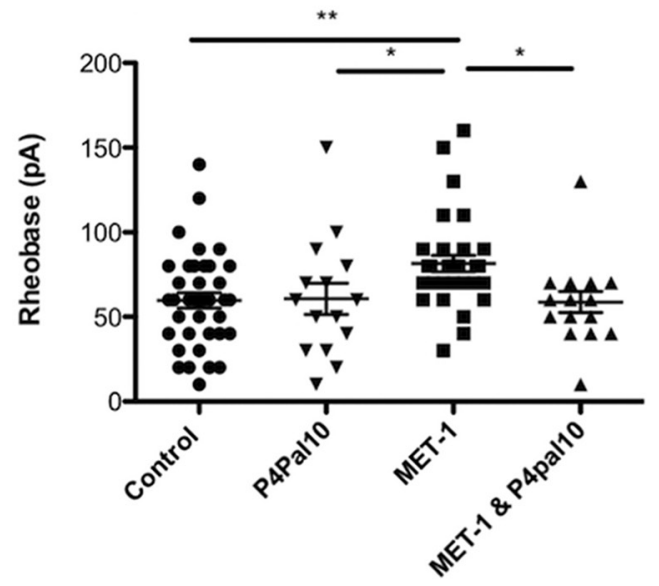

B

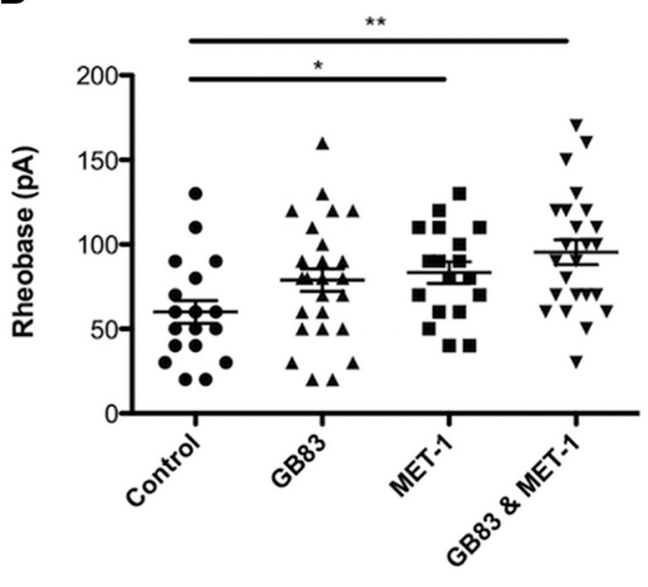

Figure 5. Effects of MET-1 on excitability of DRG neurons is through PAR-4 and not PAR-2. A, MET-1 decreased excitability of DRG neurons by increasing rheobase compared with media; this effect was abolished following preincubation of the neurons with P4pal10 (10 $\mu \mathrm{M})$, a PAR-4 receptor antagonist ( $N=7$ mice). B, GB83 (10 $\mu \mathrm{M})$, a PAR-2 receptor antagonist, did not block the effect of MET-1 on neuron excitability ( $N=8$ mice). ${ }^{*} p<0.05$ (one-way ANOVA with Newman-Keuls post hoc test). ${ }^{* *} p<0.005$ (one-way ANOVA with Newman-Keuls post hoc test). 
A

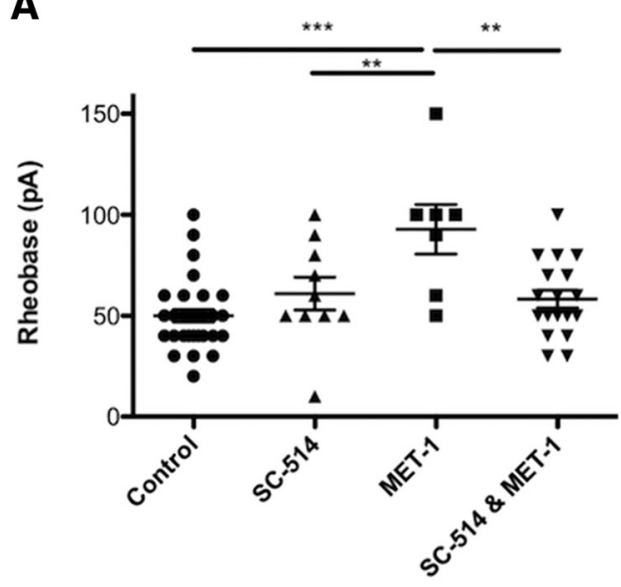

B

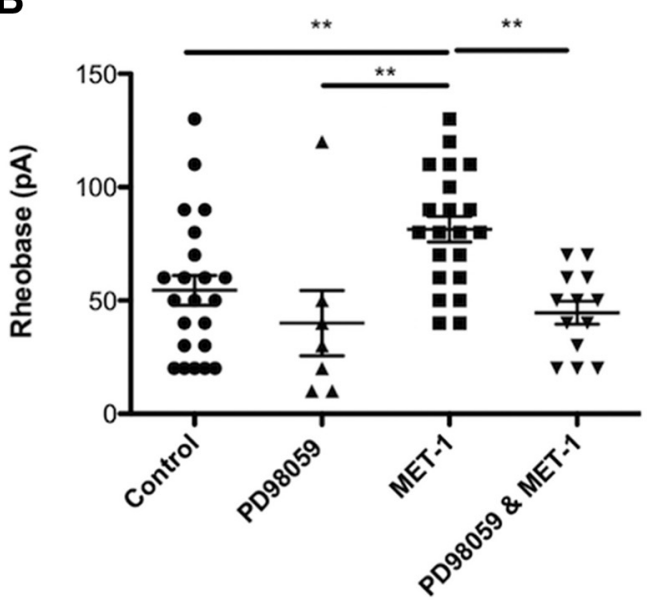

Figure 6. MET-1 decreases excitability of DRG neurons in an NF $\kappa B$ - and ERK1/2-dependent manner. $A$, MET-1 decreased excitability of DRG neurons by increasing rheobase compared with media; this effect was abolished following the addition of $S C-514(20 \mu \mathrm{m})$, an NF $\kappa$ B inhibitor ( $N=4$ mice). $B$, MET-1 decreased excitability of DRG neurons by increasing rheobase compared with media; this effect was abolished following the addition of PD98059 (30 $\mu \mathrm{m})$ an ERK1/2 kinase inhibitor ( $N=4$ mice). ${ }^{* * *} p<0.001$ (one-way ANOVA with Newman-Keuls post hoc test). ${ }^{* *} p<0.005$; (one-way ANOVA with Newman-Keuls post hoc test).

A

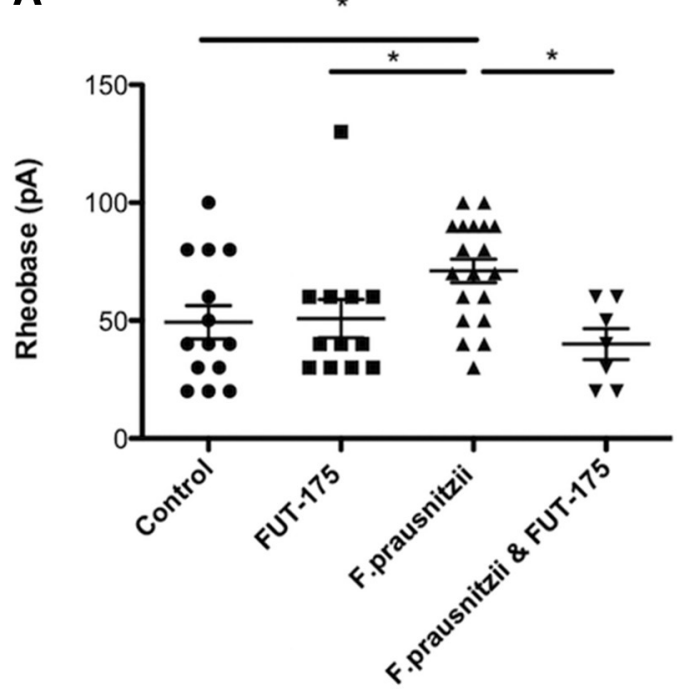

B

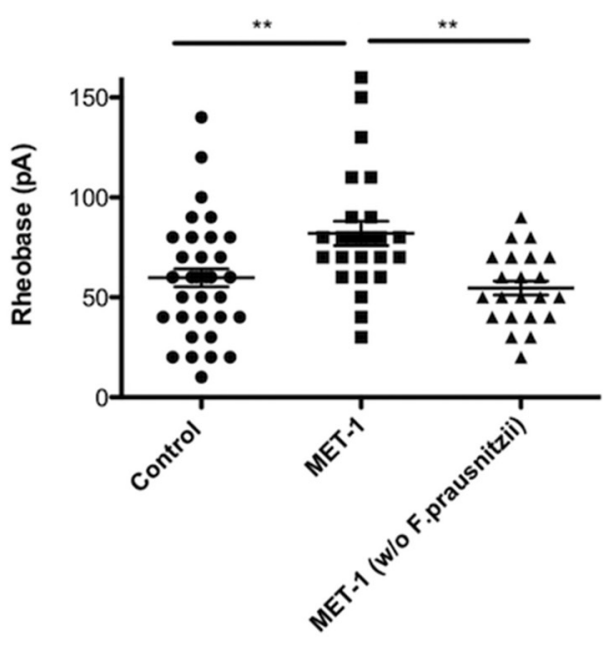

Figure 7. F. prausnitzii contributes to the effects of MET-1 on the excitability of DRG neurons. $A$, The individual strain $F$. prausnitzii (1:100) decreased excitability of DRG neurons by increasing rheobase compared with media; this effect was blocked following preincubation with FUT-175 (100 $\mu \mathrm{M})(N=5$ mice). $\boldsymbol{B}$, MET-1 grown without $F$. prausnitzii had no effect on excitability of DRG neurons compared with media ( $N=5$ mice). ${ }^{*} p<0.05$ (one-way ANOVA with Newman-Keuls post hoc test). ${ }^{* *} p<0.01$ (one-way ANOVA with Newman-Keuls post hoc test).

Subsequently, DRG neurons preincubated with PD98059 (30 $\mu \mathrm{M})$ (Dudley et al., 1995), an ERK1/2 inhibitor, for $2 \mathrm{~h}$ before the addition of MET-1 prevented the decrease in excitability of DRG neurons by MET- 1 (Fig. $6 B ; F_{(3,59)}=4.029, p=0.0005$, one-way ANOVA followed by Newman-Keuls test post hoc test).

\section{Bacterial strain-specific effects on neuronal excitability}

To determine whether individual strains of bacteria from MET-1 could have similar effects on the excitability of DRG neurons, we tested two individual strains, Bifidobacterium longum 16-6-I 4 FM (hereafter, 4M) and F. prausnitzii 16-6-I 40 FAA (hereafter, 40FAA). These strains were chosen because other strains of these species have previously been suggested to affect various nociceptive and immune responses in vivo (Underwood et al., 2014; Elian et al., 2015; Martín et al., 2015; Miquel et al., 2016). Supernatant from $F$. prausnitzii, but not the B. longum strain, used at the same concentrations as in MET-1, decreased DRG neuron excitability by increasing rheobase by $30 \%$ compared with controls $\left(t_{(31)}=\right.$ $2.60, p=0.0140$, unpaired Student's $t$ test). Furthermore, preincubation of 40FAA supernatant with the serine PI FUT-175 (100 $\mu \mathrm{M})$, for $2 \mathrm{~h}$ before overnight incubation with DRG neurons abolished this effect (Fig. $7 A ; F_{(3,48)}=4.029, p=0.0123$, one-way ANOVA followed by Newman-Keuls test post hoc test). Moreover, supernatant from MET-1 grown without the inclusion of 40FAA evoked no change in excitability of DRG neurons compared with media alone (Fig. $7 B ; F_{(2,87)}=7.369, p=0.0006$, one-way ANOVA followed by Newman-Keuls test post hoc test).

Effects of MET-1 on DRG neurons from mice with colitis

During colitis, the mucosal barrier is compromised, leading to bacterial translocation as well as exposure of nociceptive nerve terminals to inflammatory mediators. We therefore examined whether DRG neurons from mice with DSS-induced colitis responded differently to MET-1 compared with control neurons. 


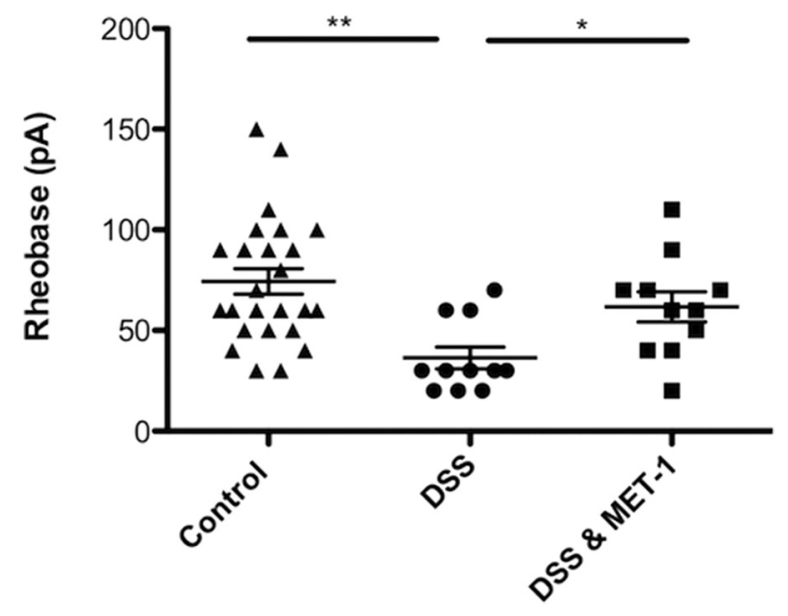

Figure 8. MET-1 reduces the excitability of DRG neurons from mice with DSS-induced colitis. MET-1 decreased the excitability of DRG neurons from DSS mice by increasing rheobase compared with neurons from DSS mice incubated in media ( $N=4$ DSS mice, $N=3$ control mice). ${ }^{*} p<0.05$ (one-way ANOVA with Newman-Keuls post hoc test). ${ }^{* *} p<0.01$ (one-way ANOVA with Newman-Keuls post hoc test).

Acute colitis was induced by administration of 3\% DSS (w/v) (MW: 36,000-50,000, MP Biomedicals) to mice in drinking water for $5 \mathrm{~d}$, followed by a $2 \mathrm{~d}$ recovery period during which normal drinking water was given (Motagally et al., 2009). DSS-induced colitis caused a decrease in colon length $\left(t_{(6)}=2.78, p=0.0318\right.$, unpaired Student's $t$ test), as well a significant increase in disease activity index score (Cooper et al., 1993) $\left(t_{(3)}=12.25, p=\right.$ 0.0012 , one sample Student's $t$ test) compared with control mice. DSS-induced colitis caused an increase in excitability of DRG neurons by decreasing rheobase by $49 \%$ compared with control mice $\left(t_{(34)}=3.74, p=0.007\right.$, unpaired Student's $t$ test $)$. MET-1 decreased excitability of DRG neurons from DSS mice by increasing rheobase by $51 \%$ compared with neurons from DSS mice incubated in media (Fig. $8 ; F_{(2,45)}=5.172, p=0.00095$, one-way ANOVA followed by Newman-Keuls test post hoc test).

\section{Discussion}

In the present study, we show that products derived from a community of human commensal GI bacteria have direct effects on sensory neurons that can contribute to the balance of pronociceptive and antinociceptive factors regulating visceral nociceptive signaling. Previous studies have implicated bacteria in a pronociceptive role, including pathogenic S. aureus (Chiu et al., 2013) and Escherichia coli O111:B4 (Ochoa-Cortes et al., 2010; Chen et al., 2015). Here we show that secretory products from commensal bacteria derived from a human donor have inhibitory effects on DRG neurons. Moreover, we show that these actions appear to result from activation of PAR-4 on DRG neurons by serine proteases that are largely derived from a single bacterium. These findings support previous work, which show beneficial effects of commercially available probiotics on visceral pain responses (Perez-Burgos et al., 2015), and serve to highlight the role of commensal bacteria in humans to regulate the excitability of sensory neurons. Our data also indicate that, whereas colonprojecting DRG neurons are inhibited by MET-1 secretions, non-colon-projecting DRG neurons may also be influenced by the secretions of members of the colonic microbiota. Interestingly, the pain that accompanies IBD and IBS, two conditions associated with microbial dysbiosis, often affects tissues outside the GI tract. Many IBD patients experience joint pain (Braken- hoff et al., 2010), and IBS is often associated with increased somatic pain perception (Bouin et al., 2001; Verne et al., 2001; Price et al., 2006).

\section{Cellular mechanisms}

Our study describes a novel cellular pathway involving protease signaling to sensory neurons. Several lines of evidence suggest that a protease activated response could play a role in the inhibitory action exhibited by MET-1. PARs are a family of G-proteincoupled receptor (subtypes 1-4), which are activated in response to extracellular cleavage of the receptor in the $\mathrm{N}$-terminal domain by proteases and can activate downstream ERK $1 / 2$ and NF $\kappa \mathrm{B}$ signaling cascades (Kanke et al., 2001; McDougall and Muley, 2015). Proteases that signal through the PAR-2 pathway cause PAR-2-induced release of pronociceptive neuropeptides and modulation of various receptors, including voltage-gated ion channels, which are important for modulation of action potential firing and thus nociceptive signaling (Mrozkova et al., 2016). In contrast to PAR-2, activation of the PAR-4 receptor has been shown to have antinociceptive effects (Asfaha et al., 2007; Augé et al., 2009; Karanjia et al., 2009). Here, we have shown that MET-1 is acting through PAR-4, also leading to inhibitory effects on DRG neurons, possibly by increasing the amplitude of voltagegated $\mathrm{K}^{+}$currents. We also observed that MET- 1 reduces $\mathrm{Ca}^{2+}$ influx into DRG neurons in response to the TRPV1 agonist capsaicin. It is presently unclear whether this effect is the result of modulation of TRPV1 channels, voltage-gated $\mathrm{K}^{+}$channels, voltage-gated $\mathrm{Ca}^{2+}$ channels, or $\mathrm{Ca}^{2+}$-induced $\mathrm{Ca}^{2+}$ release.

Single proteases can activate multiple PARs and multiple proteases can activate the same PAR. Numerous studies show evidence that serine proteases, through PAR-2, lead to an increase in neuronal excitability, in contrast to our findings (Kayssi et al., 2007; Zhao et al., 2014, 2015). The most straightforward of explanations by which MET-1 supernatant might act through PAR-4, and not PAR-2, on DRG neurons could be that the serine protease present in MET-1 supernatant selectively activates PAR-4. Although the process is poorly understood, a unique property of PAR-4, compared with PAR-1 in rat fibroblasts, is its slowed rate of internalization (Shapiro et al., 2000). This may lead to a sustained signaling, outlasting any effect of PAR-2 activation by serine proteases in MET-1 supernatant. Our results could also be explained by previous findings that show activation of PAR-4 on DRG neurons inhibited cellular responses induced by the pronociceptive agonists of PAR-2 and TRPV-4 (Augé et al., 2009; Karanjia et al., 2009). Furthermore, the serine protease, Cat G, which we have shown to recapitulate the effects of MET-1 on DRG neurons, is unable to signal through PAR-2 in endothelial cells (Loew et al., 2000). More recently, studies have shown that Cat G activates nonconical PAR-2 signaling, leading to a "silencing" of the receptor in various cell lines (Dulon et al., 2003; Ramachandran et al., 2011). Consistent with our findings, Annaházi et al. (2009) showed that the antinociceptive effects of UC fecal supernatant can be recapitulated with intracolonic infusion of a PAR-4-activating peptide or Cat G. Moreover, they showed that UC fecal supernatant, as in the diarrhea-predominant IBS fecal supernatant, does contain serine proteases acting on PAR-2 to elicit the pronociceptive effects, but they are unable to overcome the antinociceptive effects of Cat-G through PAR-4 (Annaházi et al., 2009).

\section{Bacterial sources of serine proteases}

An unanticipated finding was that the effects of MET-1 on the excitability of DRG neurons could be recapitulated with a specific 
individual strain within MET-1. Supernatant from F. prausnitzii strain 40FAA was able to reduce excitability of DRG neurons to the same degree as MET-1. Moreover, the effect of this F. prausnitzii strain was abolished following preincubation of culture supernatant with the serine PI FUT-175, indicating that it is likely a serine protease produced by this bacterial strain that is the active component of MET-1. In addition to demonstrating the potential antinociceptive effects of 40 FAA on DRG neurons, we were able to show that removal of this strain from our original MET-1 community abolished the observed decrease in excitability of DRG neurons. This finding was of considerable interest given that $F$. prausnitzii is an abundant bacterium in the human microbiota of healthy adults and has been shown to be absent or significantly reduced in the microbiota of patients with various GI disorders, including Crohn's disease and infectious colitis (Sokol et al., 2009; Willing et al., 2009; Fujimoto et al., 2013; Pascal et al., 2017). Indeed, F prausnitzii has recently been proposed to be a biomarker for Crohn's disease (Pascal et al., 2017). F. prausnitzii exhibited anti-inflammatory effects on rodent colitis models, which were thought to be partly due to secreted metabolites (Sokol et al., 2008). A recent study supporting the potential importance of $F$. prausnitzii showed that it exhibited antinociceptive properties in vivo in noninflammatory IBS-like models (Miquel et al., 2016), although this effect was ascribed to effects of the bacterium on mucosal permeability. Our data provide the first direct evidence that strain 40 FAA may modulate pain by direct effects on DRG neurons. Moreover, we found, in a mouse model of colitis, where inflammation reduces the mucosal barrier, that secretory products of the commensal bacteria in MET-1 can reverse the hyperexcitability of DRG neurons that occurs in the model. These findings support the concept that this bacterial strain may be a promising analgesic probiotic formulation.

There is no literature to date indicating serine proteases of F. prausnitzii origin; however, there are data showing that $F$. prausnitzii is inversely correlated with human fecal protease activity (Carroll et al., 2013). However, protease analysis was limited to trypsin-like proteolytic activity, which may not detect other serine proteases, such as cathepsin G. Bacterial-derived proteolytic activity has been demonstrated to occur in fecal samples of control patients (Pruteanu et al., 2011), supporting our results indicating that commensal bacteria derived from MET-1 also shows presence of bacterial proteases. Furthermore, oral antibiotic treatment in mice resulted in decreased colonic bacteria and reduced colonic luminal serine protease activity (Róka et al., 2007). Interestingly, Annaházi et al. (2009) showed that intracolonic infusion of fecal supernatant (with elevated levels of serine protease activity) from UC patients had antinociceptive effects in mice in response to colorectal distension, whereas fecal supernatant from diarrhea-predominant IBS patients, acting through PAR-2, had pronociceptive effects.

In conclusion, pain is a major cause of morbidity in a number of chronic GI disorders and lacks effective therapies. Here, we have demonstrated that a serine protease derived from a defined community of commensal GI bacteria is capable of reducing excitability of DRG neurons through a PAR-4-dependent mechanism. These actions could be of even greater importance in disorders, such as postinfectious IBS and IBD, where dysbiosis of the commensal bacteria occurs, including reductions in $F$. prausnitzii. Furthermore, these findings serve as a cautionary note that antibiotic treatments that alter the intestinal microbiota may have effects on the excitability of sensory signaling. Finally, F. praus- nitzii and/or its secretory protease may provide a novel therapeutic agent for patients with GI diseases associated with pain.

\section{References}

Annaházi A, Gecse K, Dabek M, Ait-Belgnaoui A, Rosztóczy A, Róka R, Molnár T, Theodorou V, Wittmann T, Bueno L, Eutamene H (2009) Fecal proteases from diarrheic-IBS and ulcerative colitis patients exert opposite effect on visceral sensitivity in mice. Pain 144:209-217. CrossRef Medline

Asfaha S, Cenac N, Houle S, Altier C, Papez MD, Nguyen C, Steinhoff M, Chapman K, Zamponi GW, Vergnolle N (2007) Protease-activated receptor-4: a novel mechanism of inflammatory pain modulation. Br J Pharmacol 150:176-185. CrossRef Medline

Augé C, Balz-Hara D, Steinhoff M, Vergnolle N, Cenac NS (2009) Proteaseactivated receptor-4 (PAR4): a role as inhibitor of visceral pain and hypersensitivity. Neurogastroenterol Motil 21:1189-e107. CrossRef Medline

Beyak MJ, Ramji N, Krol KM, Kawaja MD, Vanner SJ (2004) Two TTXresistant $\mathrm{Na}^{+}$currents in mouse colonic dorsal root ganglia neurons and their role in colitis-induced hyperexcitability. Am J Physiol Gastrointest Liver Physiol 287:G845-G855. CrossRef Medline

Borruel N, Carol M, Casellas F, Antolín M, de Lara F, Espín E, Naval J, Guarner F, Malagelada JR (2002) Increased mucosal tumour necrosis factor alpha production in Crohn's disease can be downregulated ex vivo by probiotic bacteria. Gut 51:659-664. CrossRef Medline

Bouin M, Meunier P, Riberdy-Poitras M, Poitras P (2001) Pain hypersensitivity in patients with functional gastrointestinal disorders: a gastrointestinalspecific defect or a general systemic condition? Dig Dis Sci 46:2542-2548. CrossRef Medline

Brakenhoff LK, van der Heijde DM, Hommes DW, Huizinga TW, Fidder HH (2010) The joint-gut axis in inflammatory bowel diseases. J Crohns Colitis 4:257-268. CrossRef Medline

Brierley SM, Jones RC 3rd, Gebhart GF, Blackshaw LA (2004) Splanchnic and pelvic mechanosensory afferents signal different qualities of colonic stimuli in mice. Gastroenterology 127:166-178. CrossRef Medline

Bunnett NW (2006) Protease-activated receptors: how proteases signal to cells to cause inflammation and pain. Semin Thromb Hemost 32 [Suppl 1]:3948. CrossRef Medline

Carroll IM, Ringel-Kulka T, Ferrier L, Wu MC, Siddle JP, Bueno L, Ringel Y (2013) Fecal protease activity is associated with compositional alterations in the intestinal microbiota. PLoS One 8:10. CrossRef Medline

Cenac N, Andrews CN, Holzhausen M, Chapman K, Cottrell G, AndradeGordon P, Steinhoff M, Barbara G, Beck P, Bunnett NW, Sharkey KA, Ferraz JG, Shaffer E, Vergnolle N (2007) Role for protease activity in visceral pain in irritable bowel syndrome. J Clin Invest 117:636-647. CrossRef Medline

Chen S, Xiong J, Zhan Y, Liu W, Wang X (2015) Wogonin inhibits LPSinduced inflammatory responses in rat dorsal root ganglion neurons via inhibiting TLR4-MyD88-TAK1-mediated NF- $\kappa \mathrm{B}$ and MAPK signaling pathway. Cell Mol Neurobiol 35:523-531. CrossRef Medline

Chichlowski M, Rudolph C (2015) Visceral pain and gastrointestinal microbiome. J Neurogastroenterol Motil 21:172-181. CrossRef Medline

Chiu IM, Heesters BA, Ghasemlou N, Von Hehn CA, Zhao F, Tran J, Wainger B, Strominger A, Muralidharan S, Horswill AR, Bubeck Wardenburg J, Hwang SW, Carroll MC, Woolf CJ (2013) Bacteria activate sensory neurons that modulate pain and inflammation. Nature 501:52-57. CrossRef Medline

Cooper HS, Murthy SN, Shah RS, Sedergran DJ (1993) Clinicopathologic study of dextran sulfate sodium experimental murine colitis. Lab Invest 69:238-249. Medline

Cryan JF, Dinan TG (2015) More than a gut feeling: the microbiota regulates neurodevelopment and behavior. Neuropsychopharmacology 40: 241-242. CrossRef Medline

Dale C, Vergnolle N (2008) Protease signaling to G protein-coupled receptors: implications for inflammation and pain. J Recept Signal Transduct Res 28:29-37. CrossRef Medline

Dudley DT, Pang L, Decker SJ, Bridges AJ, Saltiel AR (1995) A synthetic inhibitor of the mitogen-activated protein kinase cascade. Proc Natl Acad Sci U S A 92:7686-7689. CrossRef Medline

Dulon S, Candé C, Bunnett NW, Hollenberg MD, Chignard M, Pidard D (2003) Proteinase-activated receptor-2 and human lung epithelial cells: disarming by neutrophil serine proteinases. Am J Respir Cell Mol Biol 28:339-346. CrossRef Medline

Duncker SC, Kamiya T, Wang L, Yang P, Bienenstock J (2011) Probiotic 
Lactobacillus reuteri alleviates the response to gastric distension in rats. J Nutr 141:1813-1818. CrossRef Medline

Elian SD, Souza EL, Vieira AT, Teixeira MM, Arantes RM, Nicoli JR, Martins FS (2015) Bifidobacterium longum subsp. infantis BB-02 attenuates acute murine experimental model of inflammatory bowel disease. Benef Microbes 6:277-286. CrossRef Medline

Fujimoto T, Imaeda H, Takahashi K, Kasumi E, Bamba S, Fujiyama Y, Andoh A (2013) Decreased abundance of Faecalibacterium prausnitzii in the gut microbiota of Crohn's disease. J Gastroenterol Hepatol 28:613-619. CrossRef Medline

Kamiya T, Wang L, Forsythe P, Goettsche G, Mao Y, Wang Y, Tougas G, Bienenstock J (2006) Inhibitory effects of Lactobacillus reuteri on visceral pain induced by colorectal distension in Sprague-Dawley rats. Gut 55:191-196. CrossRef Medline

Kanke T, Macfarlane SR, Seatter MJ, Davenport E, Paul A, McKenzie RC, Plevin R (2001) Proteinase-activated receptor-2-mediated activation of stress-activated protein kinases and inhibitory NF $\kappa$ B kinases in NCTC 2544 keratinocytes. J Biol Chem 276:31657-31666. CrossRef Medline

Karanjia R, Spreadbury I, Bautista-Cruz F, Tsang ME, Vanner S (2009) Activation of protease-activated receptor- 4 inhibits the intrinsic excitability of colonic dorsal root ganglia neurons. Neurogastroenterol Motil 21: 1218-1221. CrossRef Medline

Kayssi A, Amadesi S, Bautista F, Bunnett NW, Vanner S (2007) Mechanisms of protease-activated receptor 2-evoked hyperexcitability of nociceptive neurons innervating the mouse colon. J Physiol 580:977-991. CrossRef Medline

Kishore N, Sommers C, Mathialagan S, Guzova J, Yao M, Hauser S, Huynh K, Bonar S, Mielke C, Albee L, Weier R, Graneto M, Hanau C, Perry T, Tripp CS (2003) A selective IKK-2 inhibitor blocks NF- $\kappa$ B-dependent gene expression in interleukin- $\beta$-stimulated synovial fibroblasts. J Biol Chem 278:32861-32871. CrossRef Medline

Loew D, Perrault C, Morales M, Moog S, Ravanat C, Schuhler S, Arcone R, Pietropaolo C, Cazenave JP, van Dorsselaer A, Lanza F (2000) Proteolysis of the exodomain of recombinant protease-activated receptors: prediction of receptor activation or inactivation by MALDI mass spectrometry. Biochemistry 39:10812-10822. CrossRef Medline

Lynn PA, Blackshaw LA (1999) In vitro recordings of afferent fibres with receptive fields in the serosa, muscle and mucosa of rat colon. J Physiol 518:271-282. CrossRef Medline

Lyte M (2014) Microbial endocrinology: host-microbiota neuroendocrine interactions influencing brain and behavior. Gut Microbes 5:381-389. CrossRef Medline

Mackey BM, Miles CA, Parsons SE, Seymour DA (1991) Thermal denaturation of whole cells and cell components of Escherichia coli examined by differential scanning calorimetry. J Gen Microbiol 137:2361-2374. CrossRef Medline

Martín R, Miquel S, Chain F, Natividad JM, Jury J, Lu J, Sokol H, Theodorou V, Bercik P, Verdu EF, Langella P, Bermúdez-Humarán LG (2015) Faecalibacterium prausnitzii prevents physiological damages in a chronic low-grade inflammation murine model. BMC Microbiol 15:67. CrossRef Medline

Martz SL, McDonald JA, Sun J, Zhang YG, Gloor GB, Noordhof C, He SM, Gerbaba TK, Blennerhassett M, Hurlbut DJ, Allen-Vercoe E, Claud EC, Petrof EO (2015) Administration of defined microbiota is protective in a murine Salmonella infection model. Sci Rep 5:16094. CrossRef Medline

McDougall JJ, Muley MM (2015) The role of proteases in pain. Handb Exp Pharmacol 227:239-260. CrossRef Medline

McKernan DP, Fitzgerald P, Dinan TG, Cryan JF (2010) The probiotic Bifidobacterium infantis 35624 displays visceral antinociceptive effects in the rat. Neurogastroenterol Motil 22:1029-1035, e268. CrossRef Medline

Miquel S, Martín R, Lashermes A, Gillet M, Meleine M, Gelot A, Eschalier A, Ardid D, Bermúdez-Humarán LG, Sokol H, Thomas M, Theodorou V, Langella P, Carvalho FA (2016) Anti-nociceptive effect of Faecalibacterium prausnitzii in non-inflammatory IBS-like models. Sci Rep 6:19399. CrossRef Medline

Motagally MA, Neshat S, Lomax AE (2009) Inhibition of sympathetic $\mathrm{N}$-type voltage-gated $\mathrm{Ca}^{2+}$ current underlies the reduction in norepinephrine release during colitis. Am J Physiol Gastrointest Liver Physiol 296:G1077-G1084. CrossRef Medline

Mrozkova P, Palecek J, Spicarova D (2016) The role of protease-activated receptor type 2 in nociceptive signaling and pain. Physiol Res 65:357-367. Medline
Munoz S, Guzman-Rodriguez M, Sun J, Zhang YG, Noordhof C, He SM, Allen-Vercoe E, Claud EC, Petrof EO (2016) Rebooting the microbiome. Gut Microbes 7:353-363. CrossRef Medline

Ochoa-Cortes F, Ramos-Lomas T, Miranda-Morales M, Spreadbury I, Ibeakanma C, Barajas-Lopez C, Vanner S (2010) Bacterial cell products signal to mouse colonic nociceptive dorsal root ganglia neurons. Am J Physiol Gastrointest Liver Physiol 299:G723-G732. CrossRef Medline

Pascal V, Pozuelo M, Borruel N, Casellas F, Campos D, Santiago A, Martinez X, Varela E, Sarrabayrouse G, Machiels K, Vermeire S, Sokol H, Guarner F, Manichanh C (2017) A microbial signature for Crohn's disease. Gut 66:813-822. CrossRef Medline

Perez-Burgos A, Wang L, McVey Neufeld KA, Mao YK, Ahmadzai M, Janssen LJ, Stanisz AM, Bienenstock J, Kunze WA (2015) Transient receptor potential vanilloid 1 channel in rodents is a major target for antinociceptive effect of the probiotic L. reuteri DSM 17938. J Physiol 593:3943-3957. CrossRef Medline

Petrof EO, Gloor GB, Vanner SJ, Weese SJ, Carter D, Daigneault MC, Brown EM, Schroeter K, Allen-Vercoe E (2013) Stool substitute transplant therapy for the eradication of Clostridium difficile infection: "RePOOPulating" the gut. Microbiome 1:3. CrossRef Medline

Price DD, Zhou Q, Moshiree B, Robinson ME, Verne GN (2006) Peripheral and central contributions to hyperalgesia in irritable bowel syndrome. J Pain 7:529-535. CrossRef Medline

Pruteanu M, Hyland NP, Clarke DJ, Kiely B, Shanahan F (2011) Degradation of the extracellular matrix components by bacterial-derived metalloproteases: implications for inflammatory bowel diseases. Inflamm Bowel Dis 17:1189-1200. CrossRef Medline

Róka R, Demaude J, Cenac N, Ferrier L, Salvador-Cartier C, Garcia-Villar R, Fioramonti J, Bueno L (2007) Colonic luminal proteases activate colonocyte proteinase-activated receptor- 2 and regulate paracellular permeability in mice. Neurogastroenterol Motil 19:57-65. CrossRef Medline

Ramachandran R, Mihara K, Chung H, Renaux B, Lau CS, Muruve DA, DeFea KA, Bouvier M, Hollenberg MD (2011) Neutrophil elastase acts as a biased agonist for proteinase-activated receptor-2 (PAR 2). J Biol Chem 286:24638-24648. CrossRef Medline

Rousseaux C, Thuru X, Gelot A, Barnich N, Neut C, Dubuquoy L, Dubuquoy C, Merour E, Geboes K, Chamaillard M, Ouwehand A, Leyer G, Carcano D, Colombel JF, Ardid D, Desreumaux P (2007) Lactobacillus acidophilus modulates intestinal pain and induces opioid and cannabinoid receptors. Nat Med 13:35-37. CrossRef Medline

Sánchez de Medina F, Romero-Calvo I, Mascaraque C, Martínez-Augustin O (2014) Intestinal inflammation and mucosal barrier function. Inflamm Bowel Dis 20:2394-2404. CrossRef Medline

Shapiro MJ, Weiss EJ, Faruqi TR, Coughlin SR (2000) Protease-activated receptors 1 and 4 are shut off with distinct kinetics after activation by thrombin. J Biol Chem 275:25216-25221. CrossRef Medline

Soderholm JD, Perdue MH, Söderholm JD, Perdue MH (2001) Stress and gastrointestinal tract: II. Stress and intestinal barrier function. Am J Physiol Gastrointest Liver Physiol 280:G7-G13. Medline

Sokol H, Pigneur B, Watterlot L, Lakhdari O, Bermúdez-Humarán LG, Gratadoux JJ, Blugeon S, Bridonneau C, Furet JP, Corthier G, Grangette C, Vasquez N, Pochart P, Trugnan G, Thomas G, Blottière HM, Doré J, Marteau P, Seksik P, Langella P (2008) Faecalibacterium prausnitzii is an anti-inflammatory commensal bacterium identified by gut microbiota analysis of Crohn disease patients. Proc Natl Acad Sci U S A 105:1673116736. CrossRef Medline

Sokol H, Seksik P, Furet JP, Firmesse O, Nion-Larmurier I, Beaugerie L, Cosnes J, Corthier G, Marteau P, Doré, J (2009) Low counts of Faecalibacterium prausnitzii in colitis microbiota. Inflamm Bowel Dis 15:11831189. CrossRef Medline

Steck N, Mueller K, Schemann M, Haller D (2012) Bacterial proteases in IBD and IBS. Gut 61:1610-1618. CrossRef Medline

Stewart T, Beyak MJ, Vanner S (2003) Ileitis modulates potassium and sodium currents in guinea pig dorsal root ganglia sensory neurons. J Physiol 552:797-807. CrossRef Medline

Underwood MA, Arriola J, Gerber CW, Kaveti A, Kalanetra KM, Kananurak A, Bevins CL, Mills DA, Dvorak B (2014) Bifidobacterium longum subsp. infantis in experimental necrotizing enterocolitis: alterations in inflammation, innate immune response, and the microbiota. Pediatr Res 76: 326-333. CrossRef Medline

Valdez-Morales EE, Overington J, Guerrero-Alba R, Ochoa-Cortes F, Ibeakanma CO, Spreadbury I, Bunnett NW, Beyak M, Vanner SJ (2013a) 
Sensitization of peripheral sensory nerves by mediators from colonic biopsies of diarrhea-predominant irritable bowel syndrome patients: a role for PAR2. J Gastroenterol 108:1634-1643. CrossRef Medline

Valdez-Morales E, Guerrero-Alba R, Ochoa-Cortes F, Benson J, Spreadbury I, Hurlbut D, Miranda-Morales M, Lomax AE, Vanner S (2013b) Release of endogenous opioids during a chronic IBD model suppresses the excitability of colonic DRG neurons. Neurogastroenterol Motil 25:3946.e4. CrossRef Medline

Verne GN, Robinson ME, Price DD (2001) Hypersensitivity to visceral and cutaneous pain in the irritable bowel syndrome. Pain 93:7-14. CrossRef Medline

Wielders SJ, Bennaghmouch A, Reutelingsperger CP, Bevers EM, Lindhout T (2007) Anticoagulant and antithrombotic properties of intracellular protease-activated receptor antagonists. J Thromb Haemost 5:571-576. CrossRef Medline
Willing B, Halfvarson J, Dicksved J, Rosenquist M, Järnerot G, Engstrand L, Tysk C, Jansson JK (2009) Twin studies reveal specific imbalances in the mucosa-associated microbiota of patients with ileal Crohn's disease. Inflamm Bowel Dis 15:653-660. CrossRef Medline

Zhao P, Lieu T, Barlow N, Metcalf M, Veldhuis NA, Jensen DD, Kocan M, Sostegni S, Haerteis S, Baraznenok V, Henderson I, Lindström E, Guerrero-Alba R, Valdez-Morales EE, Liedtke W, McIntyre P, Vanner SJ, Korbmacher C, Bunnett NW (2014) Cathepsin S causes inflammatory pain via biased agonism of PAR2 and TRPV4. J Biol Chem 289:2721527234. CrossRef Medline

Zhao P, Lieu T, Barlow N, Sostegni S, Haerteis S, Korbmacher C, Liedtke W, Jimenez-Vargas NN, Vanner SJ, Bunnett NW (2015) Neutrophil elastase activates PAR2 and TRPV4 to cause inflammation and pain. J Biol Chem 290:13875-13887. CrossRef Medline 